\title{
Anterolateral Mini-open Approach to Repair Rotator Cuff tears: Mini Review
}

\author{
Ricardo Monreal* \\ Medica Vial Orthopedic Clinic, Alvaro Obregon, Mexico
}

Submission: September 20, 2020; Published: October 13, 2020

*Corresponding author: Ricardo Monreal, Medica Vial Orthopedic Clinic, Alvaro Obregon No.151, Mexico

Abstract

The rotator cuff tear was repaired by mini-open anterolateral approach using a single- or double row suture anchors technique. This technique represents a smaller deltoid-sparing version of standard open repair, preserving the deltoid origin by splitting the anterolateral raphe of the deltoid muscle and still allowing adequate exposure for rotator cuff repair. The purpose of this short review is to introduce the anterolateral approach for mini-open rotator cuff repair.

\section{Introduction}

With advances in shoulder arthroscopy, repair techniques for rotator cuff tear have evolved from open techniques to arthroscopically assisted mini-open techniques [1-4]. Its potential advantages include less postoperative pain, an extremely low deltoid morbidity and faster rehabilitation. Satisfactory clinical outcomes for mini-open technique have been well documented and compared favorably with those for open or arthroscopic repair technique $[1,2,5,6]$ therefore many surgeons still consider the mini-open technique to be the gold standard for rotator cuff repair $[3,4,6]$. Mini-open repair with a lateral deltoid-splitting approach is commonly used and generally produces good longterm results but attempts to repair a large or massive tear can still lead to significant deltoid and axillary-nerve injury from excessive traction. Assessment of medially retracted tendons or subscapularis tears is also difficult. Although the anterior approach provides good visualization and avoids axillary nerve injury, whereas assessment of posterior cuff tears by the anterior approach is difficult [7-9]. Mini-open repair using modified deltoid-on approach preserving the deltoid origin by splitting the anterolateral raphe of the deltoid muscle and still allowing adequate exposure for rotator cuff repair [10].

\section{Surgical Technique}

With patients placed in the decubitus supine position and given general anesthesia, the rotator cuff tear was repaired by mini-open technique using an anterolateral approach. A 3- to 4-cm skin incision was made from the anterolateral edge of the acromion distally, and dissection was made to the raphe between the anterior and middle deltoid (Figure 1). A stay suture was placed distally to prevent propagation of the deltoid split and potential injury to the axillary nerve. A deltoid retractor is placed for direct visualization of the rotator cuff and humeral head. As the torn tendon was tagged by traction sutures after removing the hypertrophic bursal tissue, the involvement and configuration of the torn tendon is confirmed and attempted anatomical reduction on the footprint of the greater tuberosity (Figure 2). After preparing the footprint using a ring curette or rasp, the torn tendon was repaired by single- or double row technique using suture anchors (Figure 3). If pathology of the long head of the bicep's tendon was found, tenodesis was performed under direct visualization. Wearing an abduction brace, patients began pendulum and passive range-of-motion exercises one day after surgery. They began active range-of-motion exercises six weeks after surgery, muscle-strengthening exercises at three months and occupational or sports activities at six months (Figure 4).

\section{Clinical Assessment}

Clinical outcomes for all patients were evaluated using the American Shoulder and Elbow Surgery (ASES) scoring system (shoulder index: excellent $\geq 90$; good 80-89; fair, 70-79; poor $<70)$ [11].

\section{Conclusion}

Anterolateral approach for mini-open rotator cuff repair produces satisfactory results. It may also provide better visualization for rotator cuff tears of all sizes. 


\section{Orthopedics and Rheumatology Open Access Journal (OROAJ)}

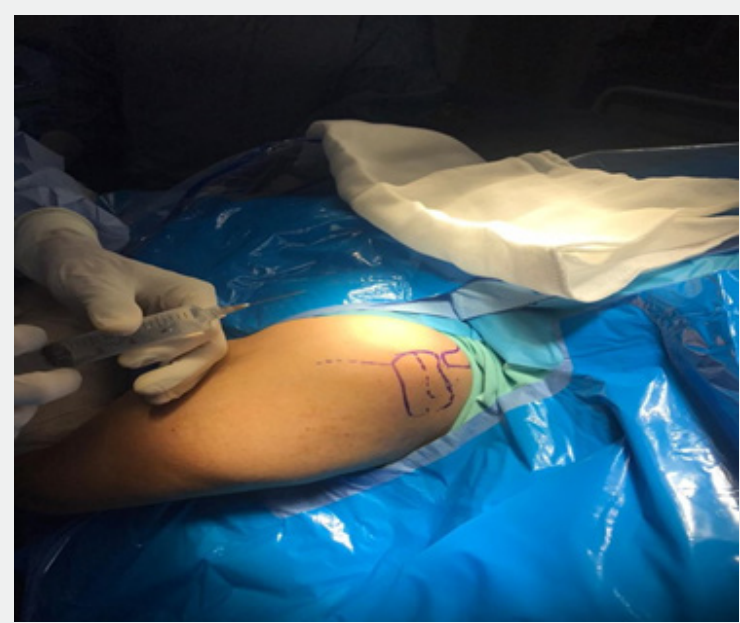

Figure 1: A 3- to 4-cm skin incision was made distally from the anterolateral edge of the acromion, with dissection to the raphe between the anterior and middle deltoid.

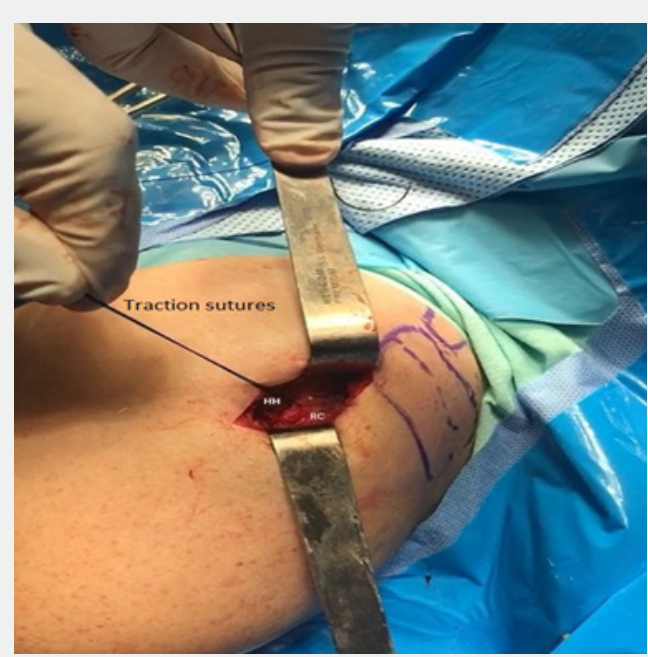

Figure 2: Placement of traction sutures after removing the hypertrophic bursal tissue and direct visualization of the torn rotator cuff (RC) and humeral head $(\mathrm{HH})$.

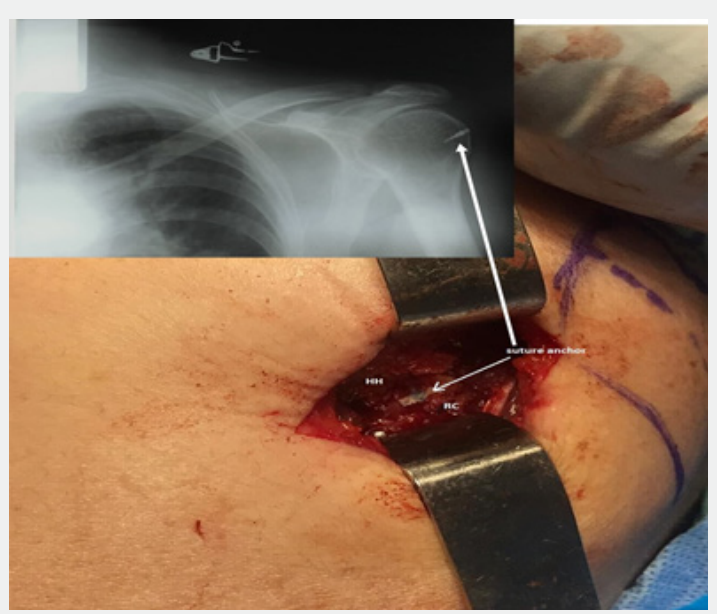

Figure 3: The torn tendon was repaired anatomically with single- or double row technique using suture anchors: Rotator cuff (RC) and humeral head $(\mathrm{HH})$ 


\section{Orthopedics and Rheumatology Open Access Journal (OROAJ)}

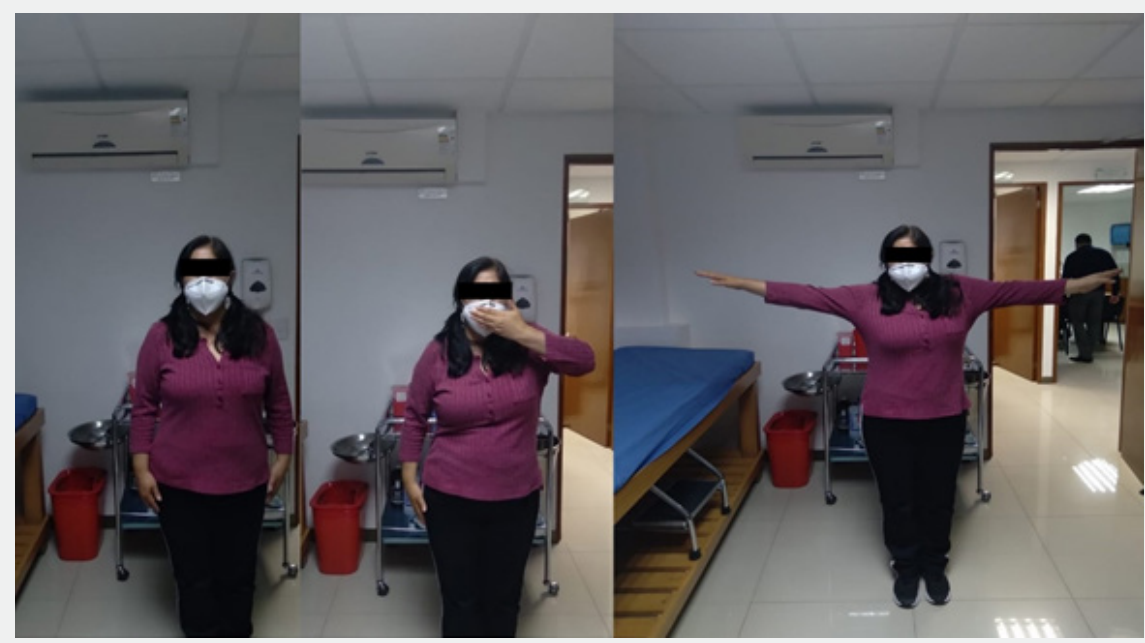

Figure 4: Clinical outcome: Shoulder index: excellent 92.

\section{References}

1. Morse K, Davis AD, Afra R, Kaye EK, Schepsis A, et al. (2008) Arthroscopic versus mini-open rotator cuff repair: a comprehensive review and meta-analysis. Am J Sports Med 36(9): 1824-1828.

2. Verma NN, Dunn W, Adler RS, Cordasco FA, Allen A, et al. (2006) Allarthroscopic versus mini-open rotator cuff repair: a retrospective review with minimum 2-year follow-up. Arthroscopy 22(6): 587-594.

3. Yamaguchi K (2001) Mini-open rotator cuff repair: an updated perspective. Instr Course Lect 50: 53-61.

4. Nho SJ, Shindle MK, Sherman SL, Freedman KB, Lyman S, et al. (2007) Systematic review of arthroscopic rotator cuff repair and mini-open rotator cuff repair. J Bone Joint Surg Am 89(3): 127-136.

5. Duquin TR, Buyea C, Bisson LJ (2010) Which method of rotator cuff repair leads to the highest rate of structural healing? A systematic review. Am J Sports Med 38(4): 835-841.

6. Osti L, Papalia R, Paganelli M, Denaro E, Maffulli N (2010). Arthroscopic vs mini-open rotator cuff repair. A quality of life impairment study. Int Orthop 34(3): 389-394

7. Hata Y, Saitoh S, Murakami N, Seki H, Nakatsuchi Y, (2001) A less invasive surgery for rotator cuff tear:mini-open repair. J Shoulder Elbow Surg 10(1): 11-16.

8. Chun JM, Kim SY, Kim JH (2008) Arthroscopically assisted minideltopectoral rotator cuff repair. Orthopedics 31(1): 74

9. Duralde XA, Greene RT (2008) Mini-open rotator cuff repair via an anterosuperior approach. J Shoulder Elbow Surg 17(5): 715-721.

10. Chul-Hyun Cho, Kwang-Soon Song, Byung-Woo Min, Gu-Hee Jung, Young-Kuk Lee, et al. (2012) Anterolateral approach for mini-open rotator cuff repair. International Orthopaedics (SICOT) 36(1): 95-100.

11. Michener LA, McClure PW, Sennett BJ (2002) American Shoulder and Elbow Surgeons Standardized Shoulder Assessment Form, patient self-report section: reliability, validity, and responsiveness. J Shoulder Elbow Surg 11(6): 587-594.

\section{Your next submission with Juniper Publishers will reach you the below assets}

- Quality Editorial service

- Swift Peer Review

- Reprints availability

- E-prints Service

- Manuscript Podcast for convenient understanding

- Global attainment for your research

- Manuscript accessibility in different formats

\section{( Pdf, E-pub, Full Text, Audio)}

- Unceasing customer service

Track the below URL for one-step submission https://juniperpublishers.com/online-submission.php 